\title{
RACANG BANGUN SISTEM INFORMASI HARGA PANGAN DAERAH KOTA PEKANBARU (STUDI KASUS: BADAN PUSAT STATISTIK RIAU)
}

\author{
${ }^{1}$ Andryan Dwi Cahyono, ${ }^{2}$ Tengku Kharil Ahsyar \\ ${ }^{1,2}$ Program Studi Sistem Informasi, Fakultas Sains dan Teknologi UIN Suska Riau \\ Jl. HR Soebrantas KM.18 Panam Pekanbaru - Riau \\ Email: ${ }^{1}$ cahyono.rian@gmail.com, ${ }^{2}$ tengkukharil@uin-suska.ac.id
}

\begin{abstract}
ABSTRAK
Ketahanan pangan mencakup empat aspek yakni ketersediaan, aksesabilitas, kestabilan harga, dan utilisasi. Satu dari empat aspek tersebut adalah kestabilan harga, yaitu disparitas harga antar daerah, antar waktu, antar pelaku, antar komoditas. Dan salah satu aspek utama dalam kestabilan harga adalah kestabilan harga volatile foods (bahan pangan strategis). Bahan pangan strategis terdiri dari sepuluh jenis bahan pangan yang dinilai menjadi pondasi utama dalam ketahanan pangan masyarakat. Salah satu cara mencapai kestabilan harga adalah transparansi dan kemudahan dalam mengetahui informasi mengenai harga bahan-bahan pangan ini. Penelitian ini bertujuan untuk membangun sebuah sistem informasi berbasis mobile, yang mencakup informasi mengenai harga pangan bahan pangan strategis di Kota Pekanbaru dan dapat di akses dengan mudah. Sistem ini berfungsi untuk menyajikan data harga pangan secara harian kepada masyarakat Kota Pekanbaru. Metode yang digunakan adalah metode deskriptif dan metode Rapid Application Development (RAD). Hasil yang dicapai dalam penelitian ini berupa suatu aplikasi mobile Android yang mencakup informasi terkait harga pangan bahan pangan strategis di Kota Pekanbaru.
\end{abstract}

Kata kunci: Ketahanan pangan, volatile foods, kestabilan harga, Rapid Application Development.

\section{PENDAHULUAN}

Perekonomian atau sistem ekonomi adalah suatu sistem yang mengatur serta menjalin hubungan ekonomi antar manusia dengan seperangkat kelembagaan dalam suatu ketahanan ${ }^{[1]}$. Dalam suatu sistem perekonomian harga pangan merupakan salah satu indikator yang dapat menjelaskan kondisi ketahanan pangan suatu wilayah. Pengamatan terhadap kondisi harga bahan pangan dapat berguna untuk berbagai hal seperti ketersediaan pasokan, permintaan, kelancaran distribusi pangan, kondisi perdagangan di pasar internasional, dampak implementasi kebijakan pemerintah, daya beli masyarakat, kesejahteraan petani/produsen ${ }^{[2]}$.

Ketahanan pangan mencakup empat aspek yakni ketersediaan (produksi, logistik, dan distribusi), aksesabilitas (akses bahan pangan untuk kaum miskin/marginal serta penanggulangan bencana), kestabilan harga (disparitas harga antar daerah, antar waktu, antar pelaku dan antar komoditas), dan utilisasi (pengolahan dan keamanan makanan $)^{[3]}$. Pada penelitian ini akan membahas satu dari keempat aspek yang disebutkan diatas, yaitu, kestabilan harga. Kestabilan harga adalah disparitas harga antar daerah, antar waktu, antar pelaku, antar komoditas atau dapat juga di artikan sebagai perbedaan harga yang terjadi antara produsen komoditas dengan konsumen akhir, yang dapat menyebabkan inflasi di kelompok volatile food (pangan strategis) ${ }^{[3]}$.

Menurut Bank Indonesia Kantor Perwakilan Riau dalam laporan Kajian Ekonomi Regional yang dirilis februari 2017, Pada triwulan IV-2016, Kota Pekanbaru mengalami inflasi sebesar 4,19\\% (yoy), lebih tinggi jika dibandingkan triwulan sebelumnya yang sebesar 3,37\\% (yoy). Meningkatnya tekanan inflasi di Kota Pekanbaru terutama bersumber dari kelompok pangan strategis yang tercatat mengalami inflasi $10,461 \%$ (yoy), lebih tinggi dibandingkan triwulan sebelumnya yang sebesar 9,60\\% (yoy).

Selain komoditas pangan beras, Pemerintah Indonesia tidak mempunyai badan khusus untuk mengintervensi pasar dalam rangka stabilisasi harga. Pemerintah menggunakan kebijakan stabilisasi yang dilakukan oleh Kementerian Pertanian dan Kementerian Perdagangan. Koordinasi antara kedua kementerian teknis ini dalam pengambilan kebijakan sangat berperan penting dalam stabilisasi harga di pasar. Kebijakan yang sering dilakukan untuk meredam gejolak kenaikan harga adalah dengan impor. Kebijakan ini seharusnya hanya bersifat jangka pendek dan sementara, karena barang impor dari negara lain biasanya sudah terdistorsi oleh subsidi yang diberikan oleh pemerintah negara asal barang impor $^{[4]}$. Kebijakan impor juga akan dipengaruhi oleh harga komoditas di pasar internasional dan nilai tukar yang berlaku pada periode pelaksanaan impor $^{[5]}$.

Sulitnya mengakses informasi dan tidak adanya sebuah platform yang dapat dijadikan sebagai sarana bertukar informasi mengenai harga pangan, merupakan salah satu alasan utama kesenjangan dan spekulasi harga di lapangan. 
Informasi yang di perlukan oleh masyarakat sebagai pelaku ekonomi adalah informasi harga pangan atau harga kebutuhan pokok masyarakat. Sesuai dengan hasil observasi di Kantor Bank Indonesia Riau dan Badan Pusat Statistik Riau, saat ini pengelolaan informasi harga pangan daerah Kota Pekanbaru di BPS Provinsi Riau belum terorganisir dengan baik. Untuk mendapatkan informasi harga pangan, masyarakat Kota Pekanbaru harus mendatangi langsung ke kantor BPS atau Bank Indonesia Provinsi Riau. Informasi harga pangan tersebut di cetak di dalam sebuah rangkuman berbentuk buku dengan judul Kajian Ekonomi Regional yang di rilis secara triwulanan yang di susun bersama oleh BPS dan Bank Indonesia Provinsi Riau. Namun, banyaknya data yang harus di olah dan panjangnya proses percetakan Kajian Ekonomi Regional tersebut, menciptakan suatu keterlambatan yang membuat perilisan kajian regional dapat terhambat hingga 512 bulan.

Untuk mengatasi permasalahan di atas maka dibangunlah sistem informasi harga pangan yang dapat memberikan informasi terkait harga pangan daerah Kota Pekanbaru, Sistem ini di harapkan mampu menangani masalah telah di paparkan.

Sistem yang dibangun untuk platform mobile Android. Sedangkan untuk pengembangan mengunakan metode Rapid Application Development (RAD) dan metode perancangan sistem menggunakan metode Object Oriented Analysis and Design (OOAD) dengan 3 diagram Unified Modeling Language (UML), yaitu Use Case Diagram, Activity Diagram dan Class Diagram. Serta dilakukan pengujian menggunakan Black-box testing dan User Acceptance Test (UAT).

\section{B. LANDASAN TEORI \\ B.1. Harga Pangan}

Pengertian pangan menurut Peraturan Pemerintah RI nomor 28 tahun 2004 adalah segala sesuatu yang berasal dari sumber hayati dan air, baik yang diolah maupun yang tidak diolah, yang diperuntukkan sebagai makanan atau minuman bagi konsumsi manusia, termasuk bahan tambahan pangan, bahan baku pangan, dan bahan lain yang digunakan dalam proses penyiapan, pengolahan, dan atau pembuatan makanan atau minuman.

Dari pemaparan penjelasan diatas, maka dapat kita simpulkan bahwa harga pangan adalah, jumlah nilai uang yang harus kita bayar dalam rangka memperoleh hasil sumberdaya hayati dan alam untuk kebutuhan makanan maupun minuman.

\section{B.2. Komoditas Pangan Strategis}

Volatile foods (komoditas pangan strategis) adalah sepuluh komoditas pangan yang memiliki kontribusi signifikan dalam pembentukan angka inflasi strategis, dengan rincian sebagai berikut ${ }^{[3]}$ :

[1] Beras: terdiri dari 6 kualitas beras berdasarkan level harga yaitu 2 jenis beras kualitas biasa/bawah, 2 jenis beras kualitas sedang, dan 2 jenis beras kualitas premium. Pemilihan jenis beras berdasarkan jenis yang paling banyak dikonsumsi masyarakat di kota/kabupaten lokasi sampel. Untuk harga beras kualitas biasa/bawah tidak termasuk beras raskin/rastra. Harga yang dilaporkan adalah harga per $\mathrm{kg}$.

[2] Bawang merah: hanya mancakup 1 kualitas bawang merah yaitu lokal dengan kualitas sedang.

[3] Bawang putih: hanya 1 kualitas bawang putih yaitu bawang putih dalam bonggol kualitas sedang.

[4] Cabai merah: terdiri dari 2 kualitas, yaitu cabai merah besar dan cabai merah keriting kualitas segar.

[5] Cabai rawit: terdiri dari 2 kualitas, yaitu cabai rawit merah dan rawit hijau dengan kualitas segar.

[6] Daging sapi: terdiri dari 2 kualitas, yaitu daging sapi has luar dan has dalam dengan kualitas segar.

[7] Daging ayam ras: hanya 1 kualitas yaitu daging ayam ras tanpa jeroan dengan kualitas segar.

[8] Telur ayam ras: hanya 1 kualitas yaitu telur ayam kualitas segar.

[9] Gula pasir: teridiri dari 2 kualitas, yaitu kualitas lokal/curah warna kuning dan kualitas premium.

[10] Minyak goreng: terdiri dari 3 kualitas, yaitu 1 kualitas lokal/curah dan 2 kualitas kemasan isi ulang.

\section{B.3. Metode Pengembangan RAD}

Pengembangan sistem informasi merupakan proses atau prosedur yang harus diikuti untuk melaksanakan seluruh langkah dalam menganalisis, merancang,mengimplementasikan, dan memelihara sistem informasi. Dalam penelitian ini penulis menggunakan metode pengembangan sistem Rapid Application Development (RAD) Model. Metodologi pengembangan sistem menggunakan pendekatan RAD menekankan pada siklus pembangunan pendek, singkat, dan cepat ${ }^{[6]}$. Waktu yang singkat adalah batasan yang penting untuk model ini. RAD menggunakan metode iteratif (berulang) dalam mengembangkan sistem dimana working model (model kerja) sistem dikonstruksikan di awal tahap pengembangan dengan tujuan menetapkan kebutuhan (requirement) user dan selanjutnya disingkirkan. Working model digunakan kadang-kadang saja 
sebagai basis desain dan implementasi sistem final ${ }^{[7]}$.

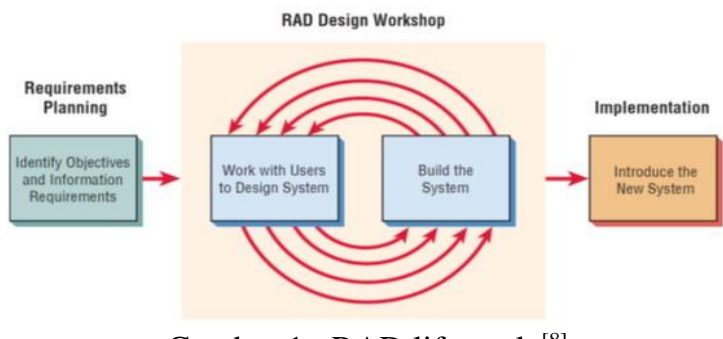

Gambar 1 : RAD life cycle ${ }^{[8]}$

\section{B.4. Black-box Testing}

Secara tradisional, teknik pengujian perangkat lunak dapat diklasifikasikan secara luas ke dalam pengujian black-box. Pengujian black-box juga disebut sebagai pengujian fungsional. Pengujian fungsional teknik yang mendesain kasus uji berdasarkan informasi dari spesifikasi. Dengan black-box penguji perangkat lunak tidak boleh (atau tidak) memiliki akses ke kode sumber internal itu sendiri. Pengujian black-box tidak berkaitan dengan mekanisme internal sistem; pengujian ini hanya fokus pada output yang dihasilkan sebagai respons terhadap input yang dipilih dan kondisi eksekusi $^{[9]}$.

Pengujian black-box merupakan pengujian user interface kepada pengguna apakah sistem dapat dioperasikan atau tidak. Pengujian ini dilakukan dengan memberikan data-data sample sebagai nilai masukan dan dibandingkan dengan informasi yang dihasilkan.

Black-box Testing tertuju pada spesifikasi fungsional dari perangkat lunak. Tester dapat mendefinisikan kumpulan kondisi input dan melakukan pengetesan pada spesifikasi fungsional program $^{[10]}$. Black-box Testing cenderung untuk menemukan hal-hal berikut:

[1] Fungsi yang tidak benar atau tidak ada.

[2] Kesalahan antarmuka (interface errors).

[3] Kesalahan pada struktur data dan akses basis data.

[4] Kesalahan performansi (performance errors).

[5] Kesalahan inisialisasi dan terminasi.

\section{B.5. User Acceptance Test (UAT)}

User Acceptance Test (UAT) adalah proses untuk mendapatkan konfirmasi bahwa sebuah sistem memenuhi yang disepakati persyaratan dan mengetes apakah semua fungsi dan fitur berjalan dengan baik. Caranya, melakukan uji coba software kepada user. Apabila hasil uji coba mendapat respon positif, maka tes tersebut dinyatakan berhasil $^{[11]}$. Rumus yang digunakan untuk menghitung keberhasilan dapat dilihat pada Rumus B.1:

$$
\text { Persentasekeberhasilan }=\frac{\text { JumlahBerhasil }}{\text { JumlahPertayaan }} \times 100
$$

\section{METODOLOGI PENELITIAN}

Pada penelitian ini terdapat 4 tahapan yang ditempuh dalam penelitian ini, dapat dilihat pada Gambar 2.

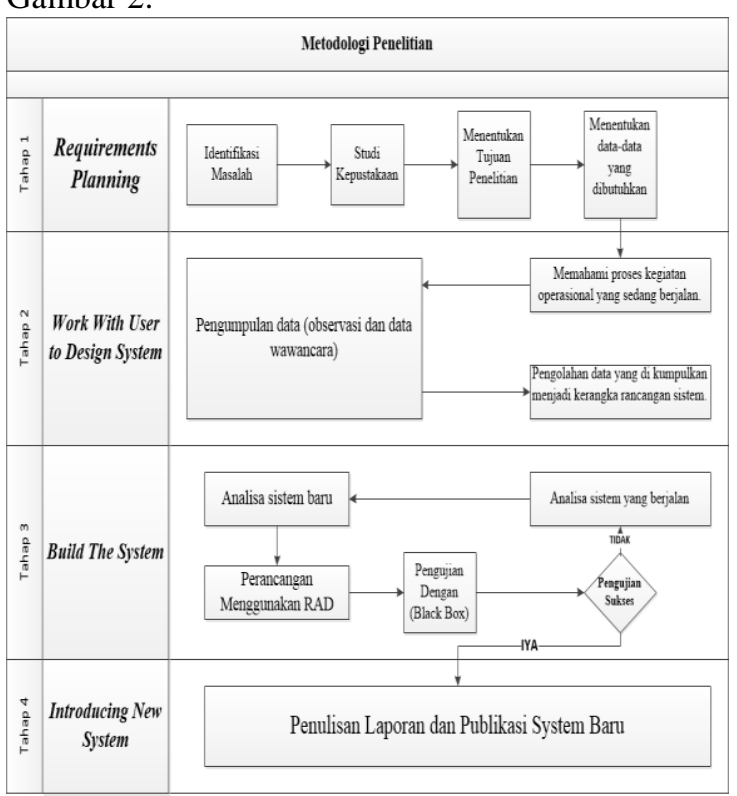

Gambar 2. Metodologi Penelitian

\section{ANALISA DAN PERANCANGAN}

\section{D.1. Analisa Sistem Berjalan}

Berdasarkan hasil survei lapangan, saat ini Bank Indonesia KPW Riau dan BPS Riau belum memiliki sistem yang terkomputasi, sehingga publikasi informasi harga pangan masih menggunakan sebuah rangkuman berbentuk buku dengn judul, Kajian Ekonomi Regional yang di rilis setiap triwulanan.

Sistem yang berjalan ini memiliki beberapa kekurangan diantaranya:

[1] Keterlambatan perilisan informasi harga hingga 5-12 bulan, dikarenakan harus menunggu semua rangkuman informasi ekonomi regional selesai.

[2] Masyarakat yang ingin mendapatkan info harga pangan harus datang langsung ke KPW Bank Indonesia Riau atau BPS.

[3] Rangkuman berbentuk buku sangat menyulitkan untuk di bawa, terlebih lagi jika membutuhkan data dalam jumlah besar.

[4] Sistem yang masih berbentuk fisik belum mendukung pencarian dan pensortiran sesuai tanggal, bulan, atau tahun.

\section{D.2. Analisa Sistem Usulan}

Sistem Informasi Harga Pangan Kota Pekanbaru, adalah sistem yang dibangun untuk menyajikan harga pangan secara akurat dan mudah. Sistem ini menyajikan harga pangan semua volatile foods dari empat pasar, yaitu Pasar Arengka, Pasar Cik Puan, Pasar Dupa, dan Pasar Sukaramai. Pengguna dapat mengakses sistem melalui perangkat Android dan sistem dapat menyajikan 
harga pangan volatile foods secara terstruktur dalam bentuk tabel. Sistem ini diharapkan mampu untuk memenuhi kebutuhan informasi mengenai harga pangan strategis di wilayah Kota Pekanbaru.

\section{D.3. Analisa Dempster Shafer}

Berikut ini adalah use case diagram aplikasi sistem informasi harga pangan Kota Pekanbaru. Dapat dilihat pada Gambar 3.

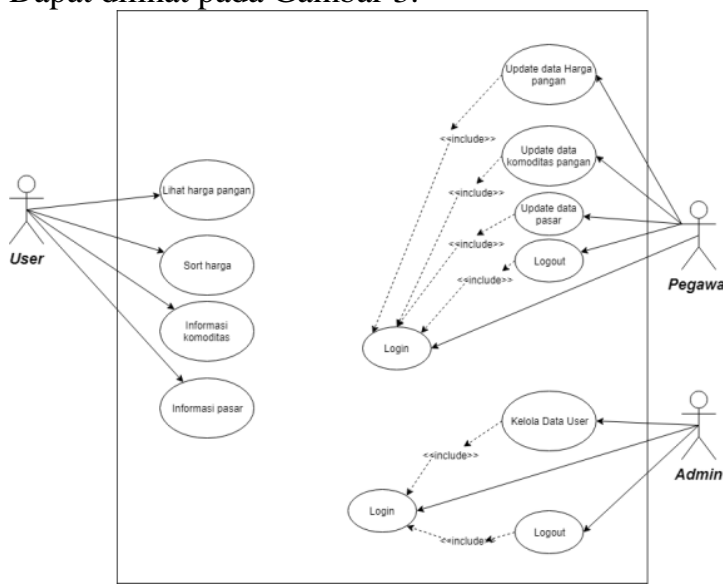

Gambar 3. Use Case Diagram Sistem Informasi Informasi Harga Pangan Kota Pekanbaru.

\section{E. HASIL IMPLEMANTASI DAN PENGUJIAN}

\section{E.1. Tampilan Halaman Utama}

Gambar 4 merupakan hasil implementasi dari menu Home. Setelah aplikasi dibuka maka halaman home akan segera tampil untuk mengakses sistem maka pengguna dapat langsung memilih menu yang ingin dibuka dengan menekan salah satu icon. Menu yang dapat dipilih diantaranya, Jenis Komoditas, Lokasi Pasar, dan Tentang Sistem. Harga pangan juga akan langsung di tampilkan sesuai database pada halaman menu ini.

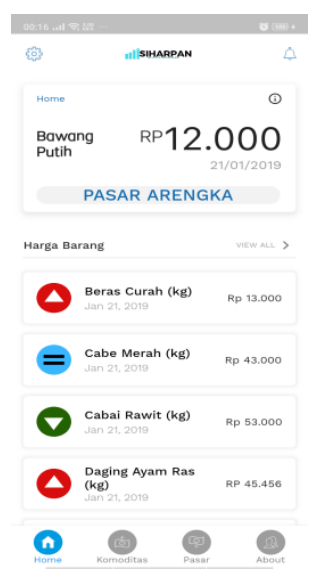

Gambar 4. Tampilan Menu Home dan Harga Pangan

\section{E.2. Tampilan Menu Komoditas}

Gambar 5 merupakan hasil implementasi dari menu Jenis Komoditas. Dari menu awal pada Gambar 4 pengguna bisa klik icon Komoditas lalu akan muncul jenis-jenis komoditas yang ada disistem, jika salah satu menu jenis komoditas tersebut di klik, maka akan menampilkan penjelasan mengenai komoditas tersebut. Seperti Gambar 6.

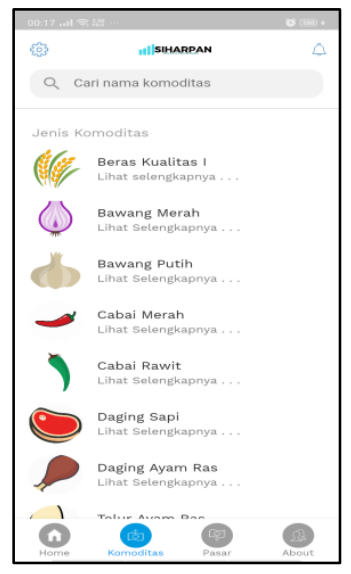

Gambar 5. Tampilan menu Komoditas.

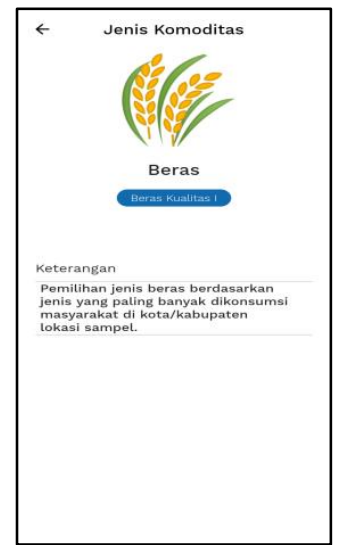

Gambar 6. Tampilan submenu penjelasan proses diagnosa.

\section{E.3. Tampilan Menu Pasar}

Gambar 7 merupakan hasil implementasi dari menu Lokasi Pasar. Dari menu awal pada gambar Gambar 4 pengguna bisa klik icon Pasar lalu akan muncul jenis-jenis pasar yang ada disistem, jika salah satu icon pasar tersebut di klik, maka akan menampilkan penjelasan mengenai pasar tersebut. Seperti Gambar 8. 


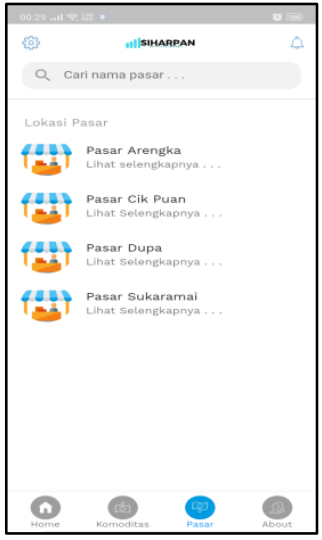

Gambar 7. Tampilan Menu Pasar

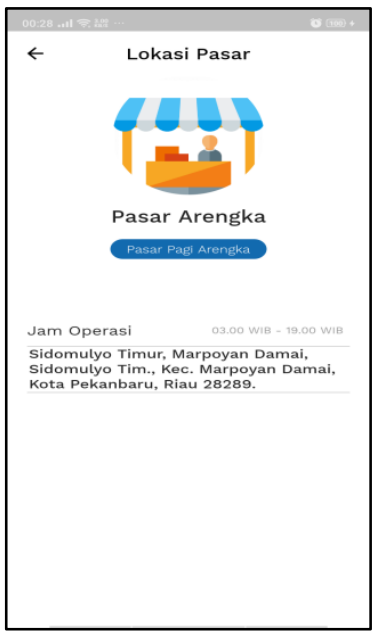

Gambar 8. tampilan submenu lokasi pasar.

\section{E.4. Tampilan Menu Tentang Sistem.}

Gambar 9 merupakan hasil implementasi dari menu Tentang Sistem. Dari menu awal pada Gambar 4 pengguna bisa klik icon About lalu akan muncul penjelasan mengenai pengembang sistem, yaitu penulis dan pembimbing penelitian penulis.

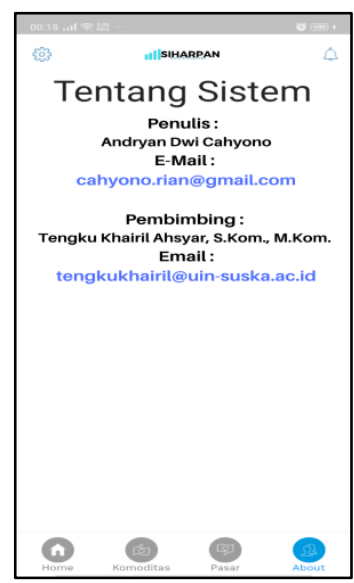

Gambar 9. Tampilan menu Tentang Sistem.

\section{E.5. Hasil Pengujian}

Berdasarkan hasil pengujian blackbox yang dilakukan dengan menggunakan sepuluh device smartphone berbeda spesifikasi, menyatakan bahwa fitur-fitur yang dibuat untuk memenuhi kebutuhan fungsional aplikasi berjalan dengan baik dengan tingkat keberhasilan 100\%.

Berdasarkan hasil pengolahan data UAT terhadap 20 orang responden, masyarakat menerima adanya aplikasi dengan tingkat penerimaan sebesar $85 \%$. Responden setuju jika tampilan aplikasi sistem informasi harga pangan menarik (pertanyaan 1) dengan tinngkat penerimaan $83,75 \%$. Responden setuju jika aplikasi membantu dalam menambah pengetahuan dan mendapatkan informasi mengenai harga pangan di Kota Pekanbaru (pertanyaan 2) dengan tingkat penerimaan $92,5 \%$. Responden setuju jika Menu yang ada di dalam aplikasi mudah dimengerti (pertanyaan 3) dengan tingkat penerimaan $83,75 \%$. Responden setuju jika aplikasi mudah digunakan (pertanyaan 4) dengan tingkat penerimaan $83,75 \%$. Dan responden setuju jika semua fitur aplikasi dapat diakses dengan baik (pertanyaan 5) dengan tingkat penerimaan $81,25 \%$.

\section{F. KESIMPULAN}

Berdasarkan hasil penelitian yang telah dilakukan dapat disimpulkan beberapa hal sebagai berikut.

[1] pada aplikasi terdapat empat menu utama yaitu menu home, menu harga pangan, menu jenis komoditas, menu lokasi pasar, dan menu tentang sistem.

[2] Aplikasi Sistem Informasi Harga Pangan Kota Pekanbaru ini berbasis mobile sehingga dapat diakses dengan mudah oleh banyak pengguna.

[3] Berdasarkan dari black-box testing yang dilakukan pada sepuluh smartphone dengan spesifikasi yang berbeda, menunjukkan bahwa aplikasi dapat berjalan dengan tingkat keberhasilan $100 \%$.

[4] Berdasarkan dari user acceptance testing yang dilakukan dengan 20 orang responden yaitu masyarakat umum menunjukkan tingkat penerimaan aplikasi adalah $85 \%$

[5] Berdasarkan black-box testing dan user acceptance testing (UAT) dapat disimpulkan bahwa sistem yang dibangun dapat direkomendasikan untuk digunakan sebagai alat bantu dalam mendapatkan informasi harga pangan dari komoditas pangan strategis di Kota Pekanbaru.

\section{REFERENSI}

[1] Dumairy. (1997). Perekonomian indonesia. Erlangga.

[2] Bank Indonesia. (2014). Kerangka penggembangan pusat informasi harga pangan stategis (pihps). Bank Indonesia dan Kementrian Koordinator Bidang Perkonomian.

[3] BPS. (2017). Kajian ekonomi dan keuangan regional provinsi kepulauan riau februari 
2017. Riau: Bank Indonesia Kantor Wilayah Riau.

[4] Sawit, M. H. (2017). Indonesia dalam perjanjian pertanian wto: Proposal harbinson. Analisis Kebijakan Pertanian, 1(1), 42-53..

[5] Chintia, S. (2013). Dampak guncangan harga minyak mentah dunia terhadap harga beras domestik.

[6] Pressman, R. S. (2005). Software engineering: a practitioner's approach. Palgrave Macmillan.

[7] Britton, C., dan Doake, J. (2000). Objectoriented system development: a gentle introduction. McGraw-Hill.

[8] Kendall, K. E., dan Kendall, J. E. (2018). Analisis dan perancangan sistem.

[9] Nidhra, S., dan Dondeti, J. (2012). Black box and white box testing techniques-a literature review. International Journal of Embedded Systems and Applications (IJESA), 2(2), 2950.

[10] Mustaqbal, M. S., Firdaus, R. F., dan Rahmadi, H. (2016). Pengujian aplikasi menggunakan black box testing boundary value analysis (studi kasus: Aplikasi prediksi kelulusan smnptn). Jurnal Ilmiah Teknologi Informasi Terapan, 1(3).

[11] Supriatin, S., Wiraatmadja, B. S., dan Luthfi, E. T. (2014). Sistem pendukung keputusan untuk menentukan penerima blsm di kabupaten indramayu. Creative Information Technology Journal, 1(4), 282-295. 